\title{
Chemical attributes of soil under cassava wastewater application in Marandugrass cultivation
}

\author{
Marcio G. da S. Bezerra ${ }^{1}$, Gualter G. C. da Silva ${ }^{2}$, Gelson dos S. Difante ${ }^{3}$, \\ João V. Emerenciano Neto ${ }^{4}$, Ermelinda M. M. Oliveira ${ }^{2} \&$ Éric G. Morais ${ }^{1}$ \\ ${ }^{1}$ Universidade Federal Rural do Semiárido/Programa de Pós-Graduação em Manejo de Solo e Água. Mossoró, RN, Brasil. E-mail: marcio_gleybson@hotmail.com \\ - ORCID: 0000-0001-9866-6617; ericmoraais@gmail.com - ORCID: 0000-0001-5936-7972 \\ ${ }^{2}$ Universidade Federal do Rio Grande do Norte/Unidade Acadêmica Especializada em Ciências Agrárias. Macaíba, RN, Brasil. E-mail:gualtermve@gmail.com \\ - ORCID: 0000-0002-4729-6449; ermelindasolos@gmail.com - ORCID: 0000-0001-7492-5776 \\ ${ }^{3}$ Universidade Federal do Mato Grosso do Sul/Faculdade de Medicina Veterinária e Zootecnia. Campo Grande, MS, Brasil. E-mail: gdifante@hotmail.com \\ - ORCID: 0000-0001-6610-8952 \\ ${ }^{4}$ Universidade Federal do Vale do São Francisco/Colegiado Acadêmico de Zootecnia. Petrolina, PE, Brasil. E-mail: joao_neto@zootecnista.com.br \\ (Corresponding author) - ORCID: 0000-0003-3060-9696
}

\begin{abstract}
There is a worldwide concern regarding the management of agroindustrial residues, involving sustainable practices that contribute to taking advantage of the residues as inputs in productive processes, allowing greater efficiency in the integration of agricultural activities and mitigating their adverse effects on the soil. Therefore, the objective of this study was to assess the effects of application of cassava wastewater on the chemical attributes of the soil cultivated with Brachiaria brizantha cv. Marandu. The experimental design was in randomized blocks with five treatments $\left(0,15,30,60\right.$ and $120 \mathrm{~m}^{3} \mathrm{ha}^{-1}$ of cassava wastewater) and four repetitions. To characterize soil chemical attributes soil samples were collected at depths 0 to 10 and 10 to $20 \mathrm{~cm}$, for determination of the concentrations of soil organic matter, available phosphorus, exchangeable potassium, sodium, calcium and magnesium before and after cassava wastewater application were determined. The application of cassava wastewater increases available phosphorus and exchangeable potassium concentrations, decreases exchangeable calcium, magnesium and organic matter contents of the soil cultivated with Marandu grass. Cassava wastewater can be used as organic fertilizer for pastures of Marandu grass with doses of up to $120 \mathrm{~m}^{3} \mathrm{ha}^{-1}$.
\end{abstract}

Key words: biofertilizer, macronutrients, 'manipueira', soil fertility

\section{Atributos químicos do solo sob aplicação de água residuária da mandioca no cultivo de capim-marandu}

RESUMO: Existe grande preocupação mundial quanto ao manejo de resíduos agroindustriais, envolvendo práticas sustentáveis que contribuam para aproveitar os resíduos como insumos em processos produtivos, possibilitando maior eficiência na integração das atividades agropecuárias e mitigando seus efeitos negativos sobre o solo. Assim, objetivou-se avaliar os efeitos da água residuária da mandioca sobre os atributos químicos do solo cultivado com Brachiaria brizantha cv. Marandu. O delineamento experimental foi em blocos ao acaso com cinco tratamentos $\left(0,15,30,60\right.$ e $120 \mathrm{~m}^{3} \mathrm{ha}^{-1}$ de água residuária da mandioca) e quatro repetições. Para a caracterização dos atributos químicos do solo foram coletadas amostras nas profundidades 0 a 10 e 10 a $20 \mathrm{~cm}$, para determinação dos teores de matéria orgânica do solo, fósforo disponível, potássio, sódio, cálcio e magnésio trocáveis antes e após a aplicação da água residuária da mandioca. A aplicação da água residuária da mandioca aumentou os teores de fósforo disponível e potássio trocável, e diminui os teores de cálcio e magnésio trocáveis, além de reduzir o teor de matéria orgânica do solo cultivado com capim-marandu. A água residuária de mandioca pode ser utilizada como fertilizante orgânico para pastos de capim-marandu com doses de até $120 \mathrm{~m}^{3} \mathrm{ha}^{-1}$.

Palavras-chave: biofertilizante, macronutrientes, manipueira, fertilidade do solo 


\section{INTRODUCTION}

The proper management of the agroindustry residues in rural properties allows greater efficiency in the integration of agricultural activities. These residues are considered to be lowcost and high-economic inputs for agriculture, in addition to the direct return of the activity (Rosa et al., 2011). Among the various residues that can be used in agriculture, the wastewater of the cassava processing industry is highlighted, popularly known in Brazilian Portuguese as 'manipueira'.

'Manipueira' is the main residue from the processing of cassava, whose appearance is a milky liquid with a high concentration of potassium, nitrogen, phosphorus, calcium, magnesium and sulfur, as well as iron and other micronutrients (Marini \& Marinho, 2011). This residue has the potential to be used as an organic fertilizer (Duarte et al., 2013), which allows high agricultural productivity in low fertility soils.

The chemical concentrations of the nutrients present in the cassava plant vary due to several factors, such as the coloration of the processed cassava pulp. Ferreira et al. (2001), analyzing the chemical characterization of 'manipueira' from cassava with white and yellow pulp and the mixture of these two, found values of $3.42,1.35$ and $2.48 \mathrm{~kg} \mathrm{~m}^{-3}$ of nitrogen; $3.09,1.69$ and $3.03 \mathrm{~kg} \mathrm{~m}^{-3}$ of potassium; $0.70,0.51$ and $0.34 \mathrm{~kg} \mathrm{~m}^{-3}$ of phosphorus; $0.19,0.16$ and $0.15 \mathrm{~kg} \mathrm{~m}^{-3}$ of calcium; and $0.60,0.38$ and $0.41 \mathrm{~kg} \mathrm{~m}^{-3}$ of magnesium, respectively. Also, the degree of processing of cassava also influences the chemical composition of the 'manipueira'. For the production of flour, the roots are less processed, especially when compared to processing to obtain the starch or gum, consequently, the concentrations of nutrients present in the 'manipueira' from the processing of cassava for the production of flour will be higher.

The use of agroindustry residues as alternative sources of fertilizers directly influences the chemical characteristics of soils and can alter $\mathrm{pH}$, electrical conductivity, nutrient concentration, among others, allowing the increase of productivity. However, if this residue is improperly used or applied in areas with a risk of damage to the environment, it can cause problems, such as: reduction of dissolved oxygen and eutrophication of water bodies, death of aquatic fauna and animals that consume water with excess hydrocyanic gas (Campos et al., 2006).

The environmental impact caused by the 'manipueira' is related to its pollution power conferred by the concentration of soluble carbohydrates that are rapidly degraded to organic acids and also to the toxicity caused by the presence of cyanogenic glycosides, which through enzymatic processes releases hydrocyanic acid that is toxic to plants (Duarte et al., 2013).

Due to high concentrations of potassium, nitrogen, phosphorus, calcium, magnesium and micronutrients, the 'manipueira' can be considered an organic fertilizer. Melo et al. (2005) observed a significant increase in the $\mathrm{pH}$ of the soil as a result of the application of 'manipueira', due to mineralization of the organic matter and the release of cations of alkali and alkaline earth metals associated with organic acids. Evaluating changes in the chemical attributes of two soils subjected to increasing doses of 'manipueira', Barreto et al. (2013) observed that the cation concentration present in this residue, as $\mathrm{K}^{+}$, $\mathrm{Ca}^{2+}, \mathrm{Mg}^{2+}$ and $\mathrm{Na}^{+}$, contributed to a significant increase in the electrical conductivity of the soil. Silva et al. (2004) verified the acidification of the soil due to the application of different doses of mature effluent from starch to sorghum, due to the decrease of soil organic carbon concentration.

The objective of this study was to evaluate the changes in the chemical attributes of the soil at two depths, under the application of cassava wastewater in pastures of Marandu grass.

\section{Material ANd Methods}

The experiment was carried out from July 2013 to January 2014, in the Experimental area of the Grupo de Pesquisa de Forragem (GEFOR), located in the Escola Agrícola de Jundiaí (EAJ), Unidade Acadêmica de Ciências Agrarias (UACIA), Universidade Federal do Rio Grande do Norte (UFRN), located in the municipality of Macaíba, RN State, which geographical coordinates are: $5^{\circ} 53^{\prime} 35.12^{\prime \prime} \mathrm{S}$ and $35^{\circ} 21^{\prime} 47.03^{\prime \prime} \mathrm{W}$, with an altitude of $50 \mathrm{~m}$.

The local climate, according to the classification of Köppen, is comprised of As' and BSh' types, characterized by dry winter, and rainy and hot summer. The region has an mean temperature of $27.1^{\circ} \mathrm{C}$ (maximum of $32{ }^{\circ} \mathrm{C}$ and a minimum of $21^{\circ} \mathrm{C}$ ), and rainfall varies between 800 and $1200 \mathrm{~mm}$ year ${ }^{-1}$. Figure 1 displays the distribution of rainfall during the period of the experiment.

The soil of the experimental area was classified as Quartzipsamments. In order to characterize the chemical attributes of the soil before the implementation of the experiment, 12 simple samples were collected in each experimental area, with the aid of an auger drilling probe, at depths of 0 to 10 and 10 to $20 \mathrm{~cm}$. Subsequently, the samples were air-dried, stripped and sieved in $2 \mathrm{~mm}$ mesh; and then homogenized to form a composite sample. The physical and chemical characterization of the soil before cultivation (Table 1) was carried out in the Laboratory of Soil and Plant Analysis of

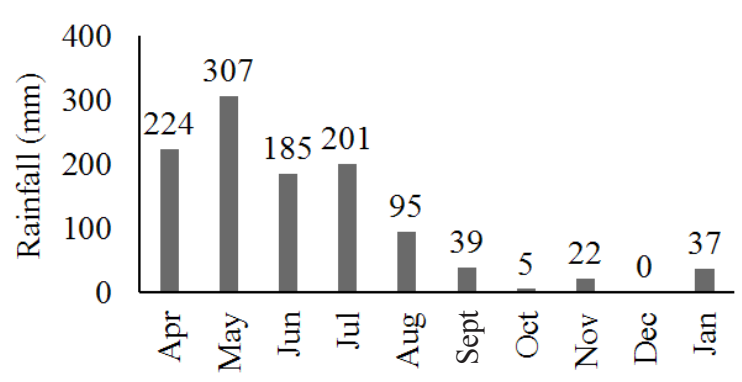

Figure 1. Rainfall from April 2013 to January 2014

Table 1. Physical and chemical attributes of the soil before cassava wastewater application

\begin{tabular}{|c|c|c|c|c|c|c|c|c|c|c|c|c|c|c|c|}
\hline \multirow{2}{*}{$\begin{array}{c}\text { Layers } \\
\text { (cm) }\end{array}$} & $\mathbf{P}$ & K & $\mathrm{Na}$ & \multirow{2}{*}{ pH } & $\mathrm{Ca}$ & $\mathrm{Mg}$ & Al & $\mathrm{H}+\mathrm{Al}$ & \multirow{2}{*}{$\begin{array}{c}\mathrm{OM} \\
\left.(\mathrm{g} \mathrm{kg})^{-1}\right)\end{array}$} & SB & CTC & \multirow{2}{*}{$\begin{array}{c}V \\
(\%)\end{array}$} & Sand & Silte & Clay \\
\hline & \multicolumn{3}{|c|}{$\left(\mathrm{mg} \mathrm{dm^{-3 } )}\right.$} & & \multicolumn{4}{|c|}{$\left(\mathrm{cmol}_{\mathrm{c}} \mathrm{dm}^{-3}\right)$} & & \multicolumn{2}{|c|}{$\left(\mathrm{cmol}_{\mathrm{c}} \mathrm{dm}^{-3}\right)$} & & \multicolumn{3}{|c|}{$\left(\mathrm{g} \mathrm{kg}^{-1}\right)$} \\
\hline $0-10$ & 5.7 & 94.5 & 36.7 & 6.8 & 1.5 & 0.8 & 0 & 1.6 & 11.8 & 2.8 & 3.1 & 91.3 & 939.5 & 20.5 & 40.0 \\
\hline $10-20$ & 2.7 & 94.5 & 47.7 & 5.6 & 0.4 & 0.2 & 0.05 & 2.3 & 6.7 & 1.2 & 2.0 & 59.1 & 939.5 & 20.5 & 40.0 \\
\hline
\end{tabular}

OM - Organic matter; SB - Sum of bases; CEC - Cation exchange capacity; V\% - Base saturation 
the Empresa de Pesquisa Agropecuária do Rio Grande do Norte (EMPARN), by the methods described by EMBRAPA (1997).

The pastures of Brachiaria brizantha cv. Marandu were planted in 2010 and grazed by sheep until 2013. During the experimental period, conventional sprinkler irrigation was used, and an average daily gross depth of $9.6 \mathrm{~mm}$ was applied at the end of the afternoon, three times a week.

The wastewater of cassava used came from a flour house located in the municipality of Ceará-Mirim, $40 \mathrm{~km}$ from the experimental area. After its collection, it underwent by a resting period of 15 days to eliminate the hydrocyanic acid by evaporation. Neves et al. (2014) studied the persistence time of the cyanide in 'manipueira' resting under natural conditions and after physical treatments. These authors verified that, regardless of the physical treatments used, at 20 days of storage the concentrations of cyanide had already reduced about six times, passing from 129.00 to $20.66 \mathrm{mg} \mathrm{L}^{-1}$, and from 50 to 60 days free cyanide was no longer identified. Meanwhile the $\mathrm{pH}$ stabilized at 80 days, being around 9.13.

The chemical characterization of the 'manipueira' was obtained from the average of two samples collected after the resting period (15 days). The chemical analyses for the determination of the macro and micronutrient concentrations were performed in the Laboratory of Water Analysis of EMPARN, following the methodology proposed by APHA (2003). The analytical results obtained were as follows: $1.54 \mathrm{~g} \mathrm{~L}^{-1}$ of nitrogen; $0.35 \mathrm{~g} \mathrm{~L}^{-1}$ of phosphorus; $2.94 \mathrm{~g} \mathrm{~L}^{-1}$ of potassium; $0.20 \mathrm{~g} \mathrm{~L}^{-1}$ of calcium; $0.38 \mathrm{~g} \mathrm{~L}^{-1}$ of magnesium; $0.44 \mathrm{~g} \mathrm{~L}^{-1}$ of sodium; $5.0 \mathrm{mg} \mathrm{L}^{-1}$ of zinc; $0.5 \mathrm{mg} \mathrm{L}^{-1}$ of copper; $22 \mathrm{mg} \mathrm{L}^{-1}$ of iron; and $4.5 \mathrm{mg} \mathrm{L}^{-1}$ of manganese.

The evaluated treatments were: $0,15,30,60$ and $120 \mathrm{~m}^{3} \mathrm{ha}^{-1}$ of cassava wastewater. Each experimental unit had an area of $12.0 \mathrm{~m}^{2}(4.0 \times 3.0 \mathrm{~m})$; the spacing between plots was $1.0 \mathrm{~m}$ and between blocks of $2.0 \mathrm{~m}$. The experimental design was a randomized blocks with five treatments and four repetitions.

The cassava wastewater doses as an organic fertilizer applied to the soil were calculated according to their mineral composition, based on potassium concentrations as a nutrient in higher concentration, as well as the recommendation of potassium fertilization for different technological levels used for pasture maintenance (Ribeiro et al., 1999). Table 2 shows the estimated amounts of the main macronutrients and sodium (beneficial element), added to the soil in each treatment by the application of cassava wastewater.

Before applying the doses of organic fertilizer, an uniformity cut of the pasture to $15.0 \mathrm{~cm}$ from the level of the ground was performed. Cassava wastewater was applied using a $10 \mathrm{~L}$ irrigator, with the doses divided into two applications, the first

Table 2. Amount of macronutrients and sodium (beneficial element), added to the soil in each treatment by cassava wastewater application

\begin{tabular}{|c|c|c|c|c|c|c|}
\hline \multirow{2}{*}{$\begin{array}{c}\text { Dose } \\
\left(\mathrm{m}^{3} \mathrm{ha}^{-1}\right)\end{array}$} & $\mathrm{N}$ & P & K & $\mathrm{Ca}$ & $\mathrm{Mg}$ & $\mathrm{Na}$ \\
\hline & \multicolumn{6}{|c|}{$\left(\mathrm{kg} \mathrm{ha}^{-1}\right)$} \\
\hline 0 & - & - & - & - & - & - \\
\hline 15 & 23.1 & 5.3 & 44.1 & 3.0 & 5.7 & 6.6 \\
\hline 30 & 46.2 & 10.5 & 88.2 & 6.0 & 11.4 & 13.2 \\
\hline 60 & 92.4 & 21.0 & 176.4 & 12.0 & 22.8 & 26.4 \\
\hline 120 & 184.8 & 42.0 & 352.8 & 24.0 & 45.6 & 52.8 \\
\hline
\end{tabular}

50\% applied after the standardization cut and the remainder immediately after the first cut. The forage was harvested (cut) every 60 days for six months, totaling three cuts, the first being in September/2013, the second in November/2013 and the third in January/2014. In all cuts, the forage was collected at $15 \mathrm{~cm}$ from the soil level.

After the third cut, 12 simple soil samples were collected at each depth (0 to 10 and 10 to $20 \mathrm{~cm}$ ) of all experimental units. Samples were collected with the aid of an auger drilling probe; then the single samples of each depth were homogenized, forming two composite samples, for each soil layer. The composite samples were placed to dry in the open air, sieved in a $2.0 \mathrm{~mm}$ mesh and sent to the Laboratory of Soil and Plant Analysis of EMPARN for chemical characterization, following the methods described by EMBRAPA (1997).

The following soil chemical attributes were determined: exchangeable calcium and magnesium obtained using the $1 \mathrm{M}$ $\mathrm{KCl}$ extraction solution, read respectively by spectrophotometry and flame photometry; available phosphorus and exchangeable sodium and potassium obtained through the Mehlich ${ }^{-1}$ extractor solution and reading by calorimetric and flame photometry, respectively. The organic matter was determined by calorimetry, using the Walkley-Black method, and the $\mathrm{pH}$ in water in the saturation extract by potentiometric method (EMBRAPA, 1997).

Data were submitted to analysis of variance (ANOVA) and the effect of the wastewater verified by analysis of regression at $\mathrm{p} \leq 0.05$ by $\mathrm{F}$ test, using the statistical software Sisvar, version 4.6 (Ferreira, 2014).

\section{Results AND Discussion}

The $\mathrm{pH}$ in the soil depth of 0 to $10 \mathrm{~cm}$ did not fit the regression equation. Meanwhile, in the depth of 10 to $20 \mathrm{~cm}$ (Figure 2A), a quadratic effect was observed in the $\mathrm{pH}$ of the soil with the application of cassava wastewater, the highest estimated value for $\mathrm{pH}$ was 6.31 for $85.6 \mathrm{~m}^{3} \mathrm{ha}^{-1}$.

The $\mathrm{pH}$ values observed in the 10 to $20 \mathrm{~cm}$ layers are in agreement with those obtained by Barreto et al. (2013), Duarte et al. (2013), Dantas et al. (2014) and Magalhães et al. (2015), when studying the $\mathrm{pH}$ response on the application of increasing doses of cassava wastewater in different soils, observed a positive linear effect on the $\mathrm{pH}$ values. On the other hand, Cabral et al. (2010) did not observe a significant difference of $\mathrm{pH}$ with the application of doses ( 0 to $\left.600 \mathrm{~m}^{3} \mathrm{ha}^{-1}\right)$ of cassava wastewater in the layers of 0.5 to 10 and 10 to $20 \mathrm{~cm}$. The authors attribute this result to the $\mathrm{pH}$ values of the soil used to be close to neutrality (6.9).

The availability of nutrients to plants is greatly influenced by soil $\mathrm{pH}$; suitable $\mathrm{pH}$ values are in the range of 5.7 to 6.5 . In this area, when only this soil chemical attribute is considered, there is no limitation to plant production, because in this case there is a reduction of soil acidity, greater availability of macronutrients and a minimum distance to micronutrient availability (Malavolta, 1997).

In the $0-10 \mathrm{~cm}$ depth, there was a significant decrease in soil organic matter concentration $(\mathrm{OM})$ as a function of the 
A.

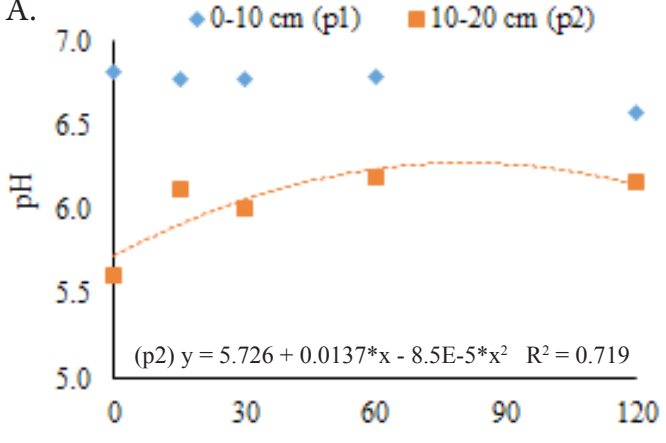

B. $\quad \diamond 0-10 \mathrm{~cm}(\mathrm{p} 1) \quad 10-20 \mathrm{~cm}(\mathrm{p} 2)$

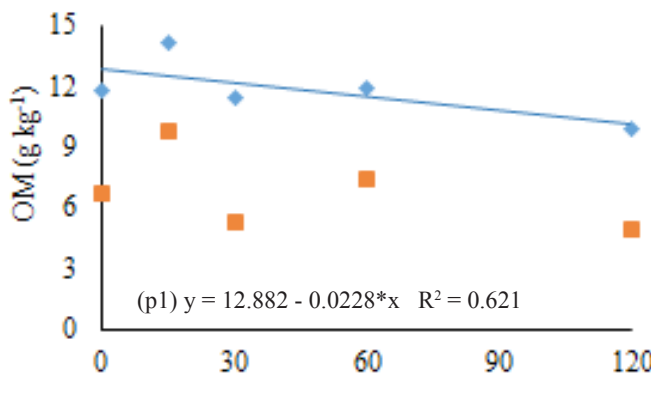

Cassava wastewater doses $\left(\mathrm{m}^{3} \mathrm{ha}^{-1}\right)$

*- Significant at $\mathrm{p} \leq 0.05$ by $\mathrm{F}$ test

Figure 2. Soil pH (A) and organic matter concentration - OM (B), at depths of 0-10 cm (p1) and 10-20 cm (p2), as a function of cassava wastewater doses applied to the soil

application of doses of cassava wastewater (Figure 2B). The $\mathrm{OM}$ reduction was of $21.3 \%$ when compared to zero and $120 \mathrm{~m}^{3} \mathrm{ha}^{-1}$ doses. A similar result was obtained by Homen et al. (2014) who, when studying the effects of the prolonged use of wastewater from pig farms applied to the soil, observed decrease in the organic matter concentration in the 0 to $20 \mathrm{~cm}$ layer after 82 days.

This result can be explained by the low carbon: nitrogen (C:N) ratio of the applied effluent, which according to Pinto et al. (2010), should be around $7 / 1$. In this condition, there will be mineralization of nitrogen that is necessary for the growth of the microorganisms, which in turn will decompose OM more quickly due to the low carbon concentration of cassava wastewater (Hernández et al., 1988). The organic matter (OM) at a depth of 10 to $20 \mathrm{~cm}$ did not differ by the use of wastewater; the mean organic matter concentration observed in this layer was $6.8 \mathrm{~g} \mathrm{~kg}^{-1}$.

According to Lampkin (1992), an adequate C:N ratio lies in a range of 25 to 35 parts of carbon to 1 of nitrogen, below that, the organic matter decomposition in the soil is accelerated due to excess of nitrogen. Potrich et al. (2014) assessed the effect of the application of different doses of nitrogen on cultural residues of sugarcane. The authors reported that nitrogen fertilization increases the rate of decomposition of dry residues of this crop as the dose of $\mathrm{N}$ applied increases. According to Hernández et al. (1988), low C:N ratio and easily degradable residues can stimulate the decomposition of the organic- $\mathrm{C}$ present in the soil, which is called "priming effect."

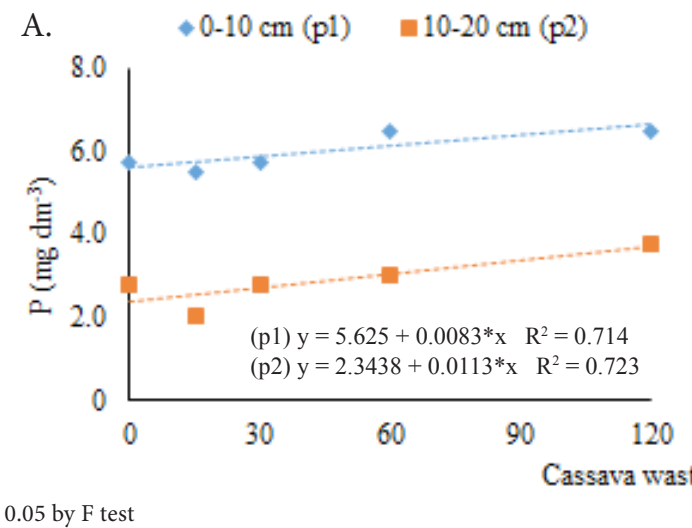

*- Significant at $\mathrm{p} \leq 0.05$ by $\mathrm{F}$ test

Figure 3. Concentration of phosphorus - P (A) and potassium - K (B) in the soil, at $0-10 \mathrm{~cm}(\mathrm{p} 1)$ and 10-20 cm (p2) depths, as a function of cassava wastewater doses applied to the soil the rate of $\mathrm{OM}$ decomposition due to the elevate growth of the microbial population when an energy-rich material is added to the system (Stevenson \& Cole, 1986). A similar result was obtained by Homen et al. (2014) who, when studying the effects of the prolonged use of wastewater from pig farms, observed a decrease in organic matter concentration in the 0 to $20 \mathrm{~cm}$ layer after 82 days.

It was verified increasing linear effect for the available phosphorus concentration as a function of the application of increasing doses of cassava wastewater at depths of 0 to 10 and 10 to $20 \mathrm{~cm}$ (Figure 3A). At a depth of 0 to $10 \mathrm{~cm}$, there was a $15.0 \%$ increase in available phosphorus concentration when comparing zero and $120 \mathrm{~m}^{3} \mathrm{ha}^{-1}$. At the depth of 10 to $20 \mathrm{~cm}$ there was an increase of $36.7 \%$ when compared the concentration of phosphorus available in the soil due to the absence of cassava wastewater.

The concentration of phosphorus in the applied waste (Table 2) and the low mobility of this mineral may justify the results obtained. Similar results were found by Duarte et al. (2013), which showed an increasing linear effect for the available phosphorus concentration of a Neosol after the application of increasing doses of cassava wastewater. Barreto et al. (2013) and Magalhães et al. (2015) also reported an increase in available phosphorus of about $60 \%$ in the soil due to the increase of cassava wastewater.

The soil phosphorus levels observed in the two depths, despite having significant increases, were well below the recommended

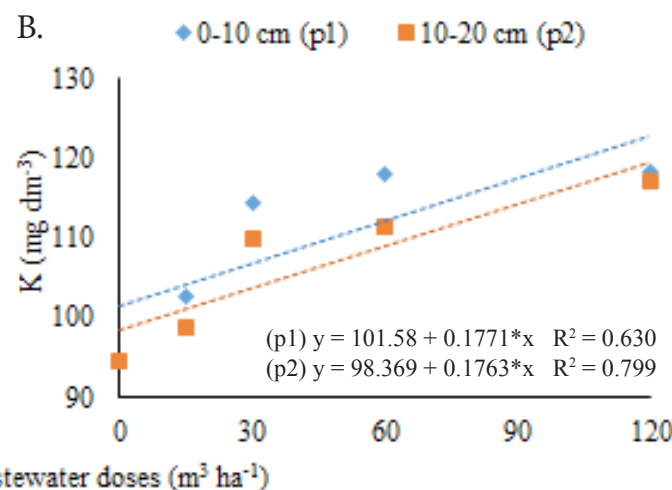
R. Bras. Eng. Agríc. Ambiental, v.23, n.8, p.579-585, 2019. 
concentrations for this class of soil, which is 21 to $30 \mathrm{mg} \mathrm{dm}^{-3}$ for most crops (Ribeiro et al., 1999). However, it is worth mentioning that the plants grown in the soil of the experimental plots that received the highest doses of cassava wastewater did not present symptoms of phosphorus nutrient deficiency.

As for exchangeable potassium, an increasing linear effect was observed (Figure 3B) at both depths ( $\mathrm{p} \leq 0.05$ ). Comparing the soils that did not receive cassava wastewater with those that received the maximum dose, the exchangeable potassium concentration at the depth of 0 to $10 \mathrm{~cm}$ increased 17.3 and $17.7 \%$ at the depth of 10 to $20 \mathrm{~cm}$. This result can be attributed to the higher concentration of this nutrient in the effluent (Table 2).

Barreto et al. (2013) also found a positive linear effect for exchangeable potassium in the soil when doses of up to $216 \mathrm{~m}^{3} \mathrm{ha}^{-1}$ of tap water were applied. Duarte et al. (2013) observed an increase in the exchangeable potassium concentration in the soil with an increase of doses of cassava wastewater from 0 to $65 \mathrm{~m}^{3} \mathrm{ha}^{-1}$, a tendency similar to the results of studies by Melo et al. (2005) and Magalhães et al. (2015).

The concentration of exchangeable calcium was adjusted to linear decreasing equation in the soil at a depth of 0 to $10 \mathrm{~cm}$ due to the application of increasing doses of cassava wastewater (Figure $4 \mathrm{~A}$ ), which led to a $21.8 \%$ decline in calcium concentration. There was no significant effect of the doses of cassava wastewater for the calcium concentration at a depth of 10 to $20 \mathrm{~cm}$.

Calcium ions are used in the synthesis of new cell walls, particularly in the middle lamella formation that separates new cells after division (Taiz \& Zeiger, 2004). Bezerra et al. (2017), when investigating the height and mass of shoots of Marandu grass plants, obtained a positive response to the increase of these variables with application of increasing doses of cassava wastewater. Based on the results of this study and on those presented by these authors it can be inferred that the demand for calcium by plants of Marandu grass may have influence on the decrease of this nutrient in the depth from 0 to $10 \mathrm{~cm}$. Also, the decrease of exchangeable calcium in the depth from 0 to $10 \mathrm{~cm}$ can also be explained by the lower contribution of this nutrient added by cassava wastewater, since it is present in a lower concentration among the macronutrients constituent of this effluent.

Similar results were observed by Homen et al. (2014), for the calcium, when used wastewater from swine in Brachiaria

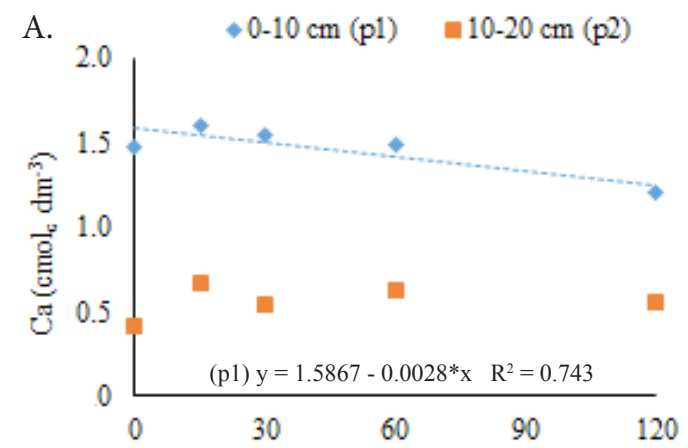

decumbens cv Basilisk plants. Dantas et al. (2014) also verified that the exchangeable calcium concentration in the soil decreased by approximately $22 \%$ with cassava wastewater in sunflower cultivation.

Despite the reduction in the exchangeable calcium concentration in the soil in the most superficial layer, the lowest value of such nutrient remains in the considered average range from 1.21 to $2.40 \mathrm{cmol} \mathrm{dm}^{-3}$ (Ribeiro et al., 1999), which indicates that cassava wastewater can meet the demands of the plant for calcium if higher amounts of this waste are used.

The exchangeable magnesium in the soil at 0 to $10 \mathrm{~cm}$ depth, adjusted to linear regression equation as a result of the application of increasing doses of cassava wastewater (Figure $4 \mathrm{~B}$ ), with a decrease of $10.0 \%$ in the soil depth of 0 to $10 \mathrm{~cm}$. There was no significant effect for the magnesium nutrient in the depth of 10 to $20 \mathrm{~cm}$.

As for calcium, it can be inferred that the decrease of exchangeable magnesium in the depth of 0 to $10 \mathrm{~cm}$ was due to the lower contribution of magnesium in cassava wastewater, because probably the amount of this nutrient replaced via organic fertilization to the soil was lower than that absorbed by the Marandu grass plants. Homen et al. (2014) also attributed this behavior to higher utilization of this nutrient by Brachiaria decumbens cv Basilisk. Dantas et al. (2014), report the same reason for the reduction of exchangeable potassium concentration in sunflower plants and Magalhães et al. (2015) in the corn crop.

There was no significant effect of the application of cassava wastewater on the exchangeable sodium concentrations in both depths, with mean values of 43.7 and $48.3 \mathrm{mg} \mathrm{dm}^{-3}$ in the layers of 0 to 10 and 10 to 20 , respectively. Thus, it can be inferred that there was no soil degradation by salinization and sodification with the application of up to $120 \mathrm{~m}^{3} \mathrm{ha}^{-1}$ of cassava wastewater. This result is quite positive, in this way one can explore the fertilization potential of the wastewater of cassava without undesirable effects on the soil, since the low sodium concentration does not limit the agricultural production under the research conditions.

Opposite results were reported by Silva et al. (2011), Barreto et al. (2013), Duarte et al. (2013) and Homen et al. (2014) noticed a tendency to salinization by the increase of exchangeable sodium with the use of wastewater as a biofertilizer. However, the divergences can be attributed to

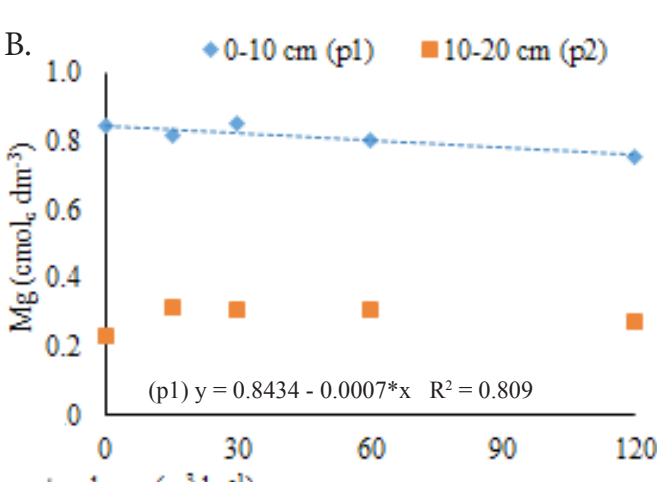

*- Significant at $\mathrm{p} \leq 0.05$ by F test

Figure 4. Concentration of calcium - $\mathrm{Ca}(\mathrm{A})$ and magnesium - Mg (B) in the soil, at 0-10 cm (p1) and 10-20 cm (p2) depths, as a function of cassava wastewater doses applied to the soil 
different wastes and/or to the highest maximum doses used by the authors: $870 \mathrm{t} \mathrm{ha}^{-1}$ of coffee wastewater, $600 \mathrm{~m}^{3} \mathrm{ha}^{-1}$ of cassava wastewater, $210 \mathrm{~m}^{3} \mathrm{ha}^{-1}$ of wastewater from cassava, $150 \mathrm{~m}^{3} \mathrm{ha}^{-1}$ of swine wastewater, respectively.

Based on the results obtained in this work and corroborating with Duarte et al. (2013), cassava wastewater may be used as an alternative source of organic fertilizer, aiming at the replacement of nutrients for the plant in order to contribute to increased productivity, and to allow the maintenance of soil fertility, avoiding its degradation. However, if such waste is not handled correctly, it may cause damage to both the environment and crops.

\section{Conclusions}

1. The application of wastewater of cassava increased the $\mathrm{pH}$, at a depth of 10 to $20 \mathrm{~cm}$, and in the concentrations of exchangeable potassium and phosphorus, available to both studied soil depths.

2. The organic matter of the soil and the calcium and magnesium concentrations at 0 to $10 \mathrm{~cm}$ depths decrease with the increment of the wastewater from cassava.

3. The application of wastewater from cassava increases the exchangeable sodium in the soil, without tendency to salinization or sodification of the studied soil.

\section{ACKnowledgments}

To the Coordenação de Aperfeiçoamento de Pessoal de Nível Superior (CAPES, Brazil), and the Escola Agrícola de Jundiaí (EAJ - UFRN) for the support and concession of the study area.

\section{Literature Cited}

APHA - American Public Health Association. Standard methods for the examination of water and wastewater. 20.ed. Washington: APHA, 2003. 3118p.

Barreto, M. T. L.; Rolim, M. M.; Pedrosa, E. M. R.; Magalhães, A. G.; Tavares U. E.; Duarte, A. S. Atributos químicos de dois solos submetidos à aplicação de manipueira. Revista Brasileira de Ciências Agrárias, v.8, p.528-534, 2013. http://dx.doi.org/10.5039/ agraria.v8i4a2425

Bezerra, M. G. S.; Silva, G. G. C. da; Difante, G. dos S.; Emerenciano Neto, J. V.; Oliveira, E. M. M.; Oliveira, L. E. C. de. Cassava wastewater as organic fertilizer in 'Marandu' grass pasture. Revista Brasileira de Engenharia Agrícola e Ambiental, v.21, p.404-409, 2017. http:// dx.doi.org/10.1590/1807-1929/agriambi.v21n6p404-409

Cabral, J. R.; Freitas, P. S. L.; Bertonha, A.; Muniz, A. S. Effects of wastewater from a cassava industry on soil chemistry and crop yield of lopsided oats (Avena strigosa Schreb.). Brazilian Archives of Biology and Technology, v.53, p.19-26, 2010. http://dx.doi. org/10.1590/S1516-89132010000100003

Campos, A. T.; Daga, J.; Rodrigues, E. E.; Franzener, G.; Suguiy, M. M. T.; Syperreck, V. I. G. Tratamento de águas residuárias de fecularia por meio de lagoas de estabilização. Engenharia Agrícola, v.26, p.235242, 2006. https://doi.org/10.1590/S0100-69162006000100026
Dantas, M. S. M.; Rolim, M. M.; Duarte, A. de S.; Silva, Ê. F. de F. e; Pedrosa, E. M. R.; Dantas, D. C. Chemical attributes of soil fertilized with Cassava Mill wastewater and cultivated with sunflower. The Scientific World Journal, v.2014, p.1-10, 2014. http://dx.doi.org/10.1155/2014/279312

Duarte, A. de S.; Rolim, M. M.; Silva, Ê. F. de F. e; Pedrosa, E. M. R.; Albuquerque, F. da S.; Magalhães, A. G. Alterações dos atributos físicos e químicos de um Neossolo após aplicação de doses de manipueira. Revista Brasileira de Engenharia Agrícola e Ambiental, v.17, p.938-946, 2013. http://dx.doi.org/10.1590/S1415-43662013000900005

EMBRAPA - Empresa Brasileira de Pesquisa Agropecuária. Manual de métodos de análises de solo. 2.ed. Rio de Janeiro: Embrapa Solos, 1997. 212p.

Ferreira, D. F. Sisvar: A guide for its bootstrap procedures in multiple comparisons. Ciência e Agrotecnologia, v.38, p.109-112, 2014. http://dx.doi.org/10.1590/S1413-70542014000200001

Ferreira, W. de A.; Botelho, S. M.; Cardoso, E. M. R.; Poltronieri, M. C.; Manipueira: Um adubo orgânico em potencial. Belém: Embrapa Amazônia Oriental, 2001. 21p. Documentos, 107

Hernández, T.; Costa, F.; Lax, A.; Cegarra, J.; Roig, A.; Moreno, J. I. Transformations of carbon and nitrogen in a calciorthid soil amended with a range of organic residues. Plant and Soil, v.105, p.205-211, 1988. https://doi.org/10.1007/BF02376784

Homen, B. G. C.; Almeida Neto, O. B.; Conde, M. S.; Silva, M. D.; Ferreira, I. M. Efeito do uso prolongado de água residuária da suinocultura sobre as propriedades químicas e físicas de um Latossolo Vermelho-Amarelo. Científica, v.42, p.299-309, 2014. http://dx.doi.org/10.15361/1984-5529.2014v42n3p299-309

Lampkin, N. Organic farming. Ipswich: Farming Press, 1992.

Magalhães, A. G.; Rolim, M. M.; Duarte, A. S.; Pedrosa, E. M. R.; Silva, E. F. de F. e. Chemical attributes of soil and dry mass accumulation of maize fertilized with cassava wastewater. Engenharia Agrícola, v.35, p.458-469, 2015. http://dx.doi.org/10.1590/1809-4430-Eng. Agric.v35n3p458-469/2015

Malavolta, E.; Vitti, G. C.; Oliveira, S. A. Avaliação do estado nutricional de plantas: Princípios e aplicações. 2.ed. Piracicaba: Potafos, 1997. 308p.

Marini, F. S.; Marinho, C. S. Adubação complementar para a mexeriqueira 'Rio' em sistema de cultivo orgânico. Revista Brasileira de Engenharia Agrícola e Ambiental, v.15, p.562-568, 2011. http://dx.doi.org/10.1590/S1415-43662011000600004

Melo, R. F. de; Ferreira, P. A.; Ruiz, H. A.; Matos, A. T. de; Oliveira, L. B. de. Alterações físicas e químicas em três solos tratados com água residuária de mandioca. Irriga, v.10, p.383-392, 2005. https:// doi.org/10.15809/irriga.2005v10n4p399-408

Neves, O. S. C.; Souza, A. S.; Costa, M. A.; Sousa, L. de A.; Viana, A. E. S.; Neves, V. B. F. Persistência do cianeto e estabilização do pH em manipueira. Revista Brasileira de Tecnologia Agroindustrial, v.8, p.1274-1284, 2014. https://doi.org/10.3895/S1981-36862014000100012

Pinto, P. H. M.; Camili, E. A.; Cabello, C. Processo de flotação no tratamento da manipueira originada da fabricação de farinha de mandioca. Revista de Tecnologias, v.3, p.53-62, 2010.

Potrich, D. C.; Marchetti, M. E.; Potrich, D. C.; Ensinas, S. C.; Serra, A. P.; Silva, E. F. da; Souza, N. H. de. Decomposição de resíduos culturais de cana-de-açúcar submetidos a diferentes doses de nitrogênio. Semina: Ciências Agrárias, v.35, p.1751-1759, 2014. https://doi.org/10.5433/1679-0359.2014v35n4p1751

Ribeiro, A. C.; Guimarães, P. T. G.; Alvarez V., V. H. Recomendações para o uso de corretivos e fertilizantes em Minas Gerais: Quinta aproximação. Viçosa: Comissão de Fertilidade do Solo do Estado de Minas Gerais, 1999. 359p. 
Rosa, M. F.; Souza Filho, M. S. M.; Figueiredo, M. C. B.; Morais, J. P. S.; Santaella, S. T.; Leitão, R. C. Valorização de resíduos da agroindústria. In: Simpósio Internacional sobre Gerenciamento de Resíduos Agropecuários e Agroindustriais, 2, 2011, Foz do Iguaçu. Anais... Concórdia: SBERA, 2011. p.98-105.

Silva, F. F. da; Freitas, P. S. L.; Bertonha, A.; Muniz, A. S.; Rezende, R. Impacto da aplicação de efluente maturado de fecularia de mandioca em solo e na cultura do sorgo. Acta Scientiarum. Agronomy, v.26, p.421-427, 2004. https://doi.org/10.4025/ actasciagron.v26i4.1801
Silva, G. B.; Rolim, M. M.; Pedrosa, E. M. R.; Bebé, F. V.; Silva, Ê. F. de F. e. Efeito da aplicação de água residuária da lavagem dos frutos de café sobre as propriedades químicas do solo. Engenharia Agrícola, v.31, p.158-166, 2011. http://dx.doi.org/10.1590/S010069162011000100016

Stevenson, F. J.; Cole, M. A. Cycles of soil: Carbon, nitrogen, phosphorus, sulfur, micronutrients. 2.ed. New York: John Wiley \& Sons, 1986. 380p.

Taiz, L.; Zeiger, E. Fisiologia vegetal. 3.ed. Porto Alegre: Artmed, 2004. 719p. 